\title{
Short- vs. Long-Course Antibiotic Treatment for Acute Streptococcal Pharyngitis: Systematic Review and Meta-Analysis of Randomized Controlled Trials
}

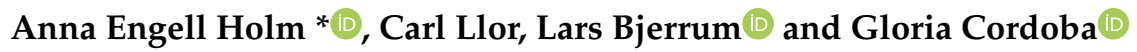 \\ Research Unit for General Practice and Section of General Practice, Department of Public Health, \\ Øster Farimagsgade 5, 1014 Copenhagen, Denmark; carles.llor@gmail.com (C.L.); lbjerrum@sund.ku.dk (L.B.); \\ gloriac@sund.ku.dk (G.C.) \\ * Correspondence: annaengellholm@gmail.com; Tel.: +45-261-110-54
}

Received: 9 September 2020; Accepted: 21 October 2020; Published: 26 October 2020

check for updates

\begin{abstract}
BACKGROUND: To evaluate the effectiveness of short courses of antibiotic therapy for patients with acute streptococcal pharyngitis. METHODS: Randomized controlled trials comparing short-course antibiotic therapy ( $\leq 5$ days) with long-course antibiotic therapy ( $\geq 7$ days) for patients with streptococcal pharyngitis were included. Two primary outcomes: early clinical cure and early bacterial eradication. RESULTS: Fifty randomized clinical trials were included. Overall, short-course antibiotic treatment was as effective as long-course antibiotic treatment for early clinical cure (odds ratio (OR) $0.85 ; 95 \%$ confidence interval (CI) 0.79 to 1.15 ). Subgroup analysis showed that short-course penicillin was less effective for early clinical cure (OR $0.43 ; 95 \%$ CI, 0.23 to 0.82 ) and bacteriological eradication (OR 0.34; 95\% CI, 0.19 to 0.61 ) in comparison to long-course penicillin. Short-course macrolides were equally effective, compared to long-course penicillin. Finally, short-course cephalosporin was more effective for early clinical cure (OR 1.48; 95\% CI, 1.11 to 1.96) and early microbiological cure (OR 1.60; $95 \%$ CI, 1.13 to 2.27 ) in comparison to long-course penicillin. In total, 1211 (17.7\%) participants assigned to short-course antibiotic therapy, and $893(12.3 \%)$ cases assigned to long-course, developed adverse events (OR 1.35; 95\% CI, 1.08 to 1.68). CONCLUSIONS: Macrolides and cephalosporins belong to the list of "Highest Priority Critically Important Antimicrobials"; hence, long-course penicillin $\mathrm{V}$ should remain as the first line antibiotic for the management of patients with streptococcal pharyngitis as far as the benefits of using these two types of antibiotics do not outweigh the harms of their unnecessary use.
\end{abstract}

Keywords: systematic review; meta-analysis; streptococcal pharyngitis; antibiotic treatment; antimicrobial resistance

\section{Introduction}

Acute pharyngitis is one of the most common complaints that a physician encounters in the ambulatory care setting, accounting for $1 \%$ to $2 \%$ of all ambulatory care visits annually and a high antibiotic prescribing rate [1,2]. However, the majority of these cases are viral and are self-limiting even in cases caused by bacteria belonging to group A streptococcus (GAS), namely "Streptococcus pyogenes" [3]. Nonetheless, there is consensus worldwide that antibiotic treatment is indicated for those with a high probability or confirmed GAS infection [4,5], specifically in high risk patients (pregnancy, HIV infection, immune deficiency).

The spread and development of antimicrobial resistance has called attention to the urgent need to optimize the use of antibiotics. Hence, the debate of whether short-term antibiotic therapy is better than long-term antibiotic treatment has gained momentum [6]. However, lack of evidence on the 
clinical effectiveness of short courses compared to long courses hampers the possibility to develop and apply novel recommendations in daily practice.

There is wide variation in clinical guidelines regarding management of acute pharyngitis caused by GAS [7]. Nonetheless, the use of a 10-day course (long course) with penicillin V is still widely accepted as a first line treatment option, as recommended by the current American and European guidelines [4,5]. Penicillin-resistant GAS has never been documented [8]. However, amoxicillin is often used in place of penicillin $\mathrm{V}$ as the first choice in some situations: 1. for young children as the efficacy appears to be equal, but this choice is primarily related to acceptance of the taste of the suspension; 2. shortage of penicillin in some countries; and 3. advantage of once-daily dosing [9,10], which may enhance adherence, and is relatively inexpensive.

There is conflicting opinions regarding the effectiveness and safety of shifting towards a shorter course. First of all, seven systematic reviews comparing short-course vs. long-course agree that short-course antibiotic treatment is non-inferior compared to long-course antibiotic treatment regarding clinical cure [11-17]. The majority of the studies included in the systematic reviews compare a short course of broad-spectrum antibiotics such as macrolides and cephalosporins with a long course of penicillin V (i.e., a narrow spectrum antibiotic). Focusing attention only on clinical effectiveness is problematic because the use of broad-spectrum antibiotics favors the development of antimicrobial resistance. Furthermore, a systematic review found that short antibiotic courses for streptococcal pharyngitis are inferior to eradicate GAS at end-of-therapy [18], in line with a recent trial published last year, which compared short vs. long courses of penicillin V in patients with GAS pharyngotonsillitis [19]. Based on this, it remains unclear whether short courses are a good option in comparison to long courses in the management of patients with pharyngitis caused by GAS.

This study aims to assess the clinical and bacteriological effectiveness and safety of short-term antibiotic therapy in comparison with long-term antibiotic regimens for the management of GAS pharyngitis in patients seeking care in primary care.

\section{Methods}

\subsection{Types of Studies}

Randomized controlled trials compared short-term vs. long-term antibiotic courses. We excluded studies in languages other than English, French, Spanish and German. Furthermore, we excluded studies comparing antibiotics with another type of treatment or patients requiring hospitalization at enrolment to treatment.

\subsection{Types of Participants}

All patients (i.e., adults and children) managed in primary care with confirmed GAS pharyngitis. The diagnosis of GAS had to be confirmed by a positive throat culture, rapid test (antigen detection test) or both.

\subsection{Types of Interventions and Outcomes}

Short-term ( 5 days or less) of antibiotic therapy and standard longer courses ( 7 days or more). Two primary outcomes were considered: early clinical cure, defined as the absence of fever and/or persistent pharyngeal pain within two weeks after completion of antibiotic treatment; early bacterial eradication, defined as a negative culture of a throat swab obtained within two weeks after completion of antibiotic treatment. The secondary outcomes were late clinical cure, defined as the absence of fever and/or persistent pharyngeal pain two weeks after completion of antibiotic treatment; late bacterial eradication, defined as a negative culture of a throat swab or recurrence obtained at least two weeks after completion of antibiotic treatment; and adverse events, such as diarrhea and rash. 


\subsection{Search Strategy and Selection Criteria}

We searched in PUBMED/Medline (January 1966 to December 2019). We used a broad search string to increase the sensitivity of the search [20]. The following search terms were used: (((("Anti-Bacterial Agents"[Mesh]) AND antibiotic*[Text Word])) AND (((("Pharyngitis/drug therapy”[Mesh]) OR sore throat*[Text Word] OR pharyngitis[Text Word]) OR tonsillopharyngitis[Text Word]) OR throat, sore[Text Word])) AND ("Tonsillitis/drug therapy"[Mesh] OR sore throat*[Text Word] OR tonsillitis[Text Word]) OR tonsillopharyngitis[Text Word]) OR throat, sore[Text Word]. Additionally, we hand-searched reference lists of all the articles identified by the above-mentioned methods.

\section{Data Collection}

Literature search, screening of title and abstract were independently performed by two reviewers (AEH, CL). The program Covidence ${ }^{\circledR}$ (Melbourne, Australia) was used for screening. Duplicates were removed, and articles were selected according to our inclusion criteria. After this step, full-text reports were assessed for eligibility. Any discrepancies were discussed with a third reviewer (GC). We extracted data on the number of participants, age, gender, diagnostic criteria and sponsorship. To assess differences in the intervention, we extracted data on type of antibiotic, dose, schedule and length. Some papers compared more than one short- or long-term course of antibiotics. In that case, we added up all the participants assigned to these courses for the main analyses. In other cases, different doses of the same short-term antibiotics were evaluated, and similarly, they all were included for the analyses. We also extracted data on microbiological results and reporting of adverse events.

\subsection{Risk of Bias}

The methodological quality of the studies was assessed according to risk of bias using the Cochrane Risk-Of-Bias (ROB) tool [21]. Risk of bias was labelled as: low (methods clearly described and adequate), high (methods described and inadequate) or unclear (insufficient information to assess the quality of the methods). Quality was assessed in the following domains: sequence generation, allocation concealment, blinding of participants/personnel, blinding of outcome assessors, incomplete outcome data and selective outcome reporting. To assess selective outcome reporting, we searched the World Health Organization International Clinical Trial Registry Platform (WHO ICTRP) [22] and the US National Institute of Health Ongoing Trials Register for completed and ongoing trials (clinicaltrials.gov) (Bethesda, MD, USA).

\subsection{Analysis}

The primary and secondary outcomes are dichotomous; hence, they are presented as the odds ratio (OR) with $95 \%$ confidence intervals (CIs). We analyzed only the available data and contacted authors to ask for further data collected in this century but did not contact authors of papers published more than 20 years ago. We tested for heterogeneity using the $\mathrm{z}$ score, $\mathrm{chi}^{2}$ test and $\mathrm{I}^{2}$ test statistics with values greater than $50 \%$ indicating substantial heterogeneity. Meta-analyses of the primary and secondary outcomes were performed using a random-effect model, since we expected a high degree of variability between the included studies. We used intention-to-treat (ITT) when data were available (i.e., the number of participants randomized was used as the denominator for each outcome). We performed subgroup analysis for trials with: (a) short-course penicillin vs. long-course penicillin, (b) short-course macrolides vs. long-course penicillin and (c) short-course cephalosporins vs. long-course penicillin. The statistical analyses were performed in the program Review Manager v5.3 ${ }^{\circledR}[23]$, which applies the Cochran-Mantel-Haenszel method for meta-analyses. 


\section{Results}

The MEDLINE search yielded 1053 articles. A total of 968 studies were excluded based on title and 28 studies were also excluded based on abstract (Figure 1). Three more papers were excluded as they were subreports of papers already included in the review. Hence, 50 randomized clinical trials were included in the study.

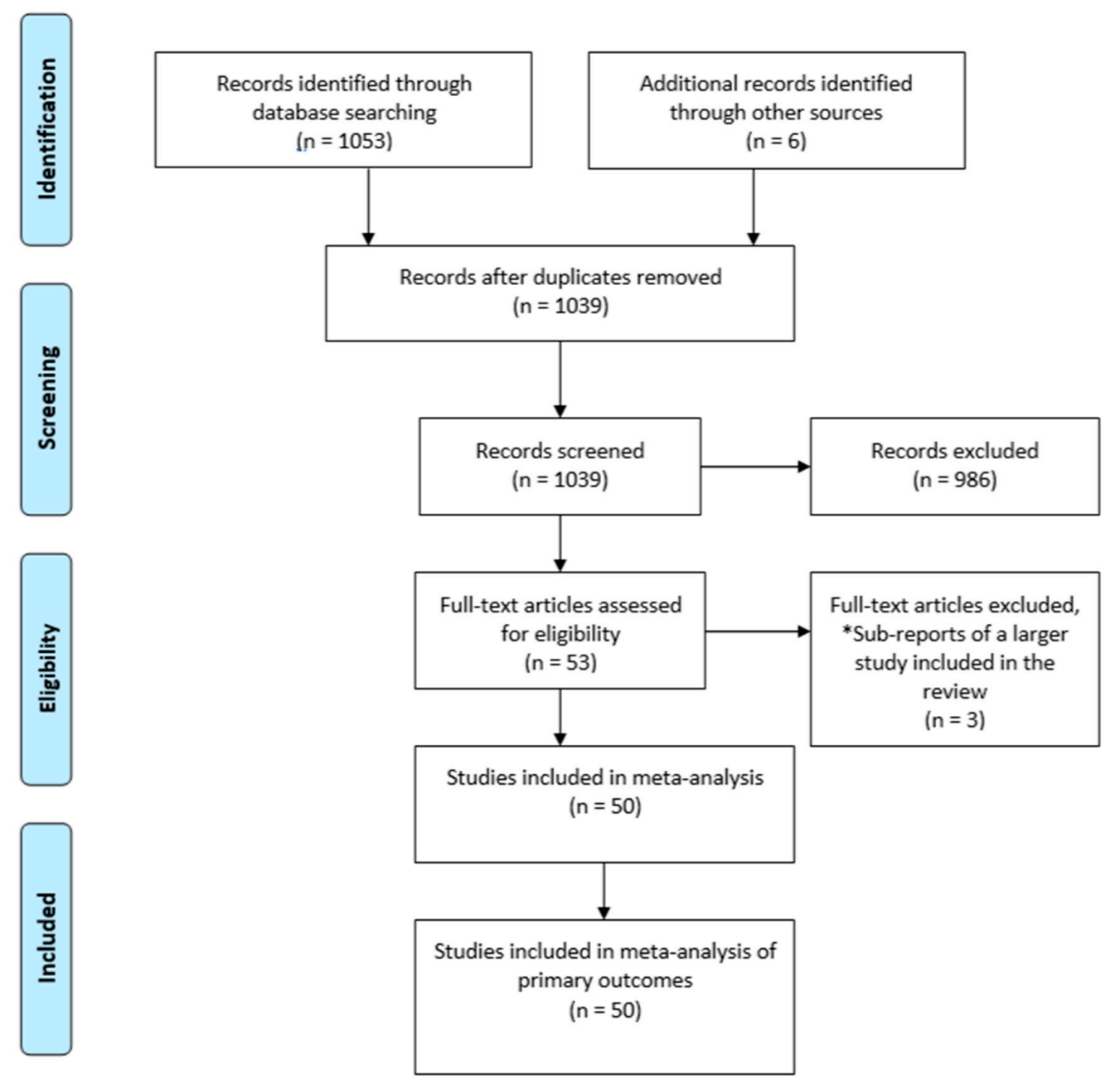

Figure 1. Preferred reporting items for systematic reviews and meta-analysis (PRISMA) flow diagram.

\subsection{Characteristics of the Included Studies}

Table 1 shows the characteristics of the included studies. The oldest report is from 1972, while the latest report is from 2019 [24-71]. The included studies investigated a total of 19,004 patients. A total of 46 studies were published in English, three in French and one in Spanish. Five clinical trials compared short vs. long courses of penicillin, while the other 45 studies compared a total of 48 short courses of broad-spectrum antibiotic therapy: 28 with macrolides, 16 with cephalosporins, 3 with amoxicillin and clavulanate and one with a lincosamide. The most commonly antibiotic used for comparison was penicillin $\mathrm{V}$, in 36 studies, of which 33 considered a 10-day course and the other three used a 7-day regimen. Twenty-four (48\%) of the studies were financed by private companies, 22 (44\%) did not report the funding sources and $4(8 \%)$ were publicly funded. In the quality assessment, we found great weaknesses. Although all trials were randomized, up to $75 \%$ of the trials did not sufficiently describe the procedures to properly classify the risk of bias from the random sequence generation. The majority of the included studies had high risk of bias regarding blinding of participants and personnel, as well as blinding of outcome assessment (Figure 2). 
Table 1. Characteristics of the 50 trials included in the meta-analyses.

\begin{tabular}{|c|c|c|c|c|c|c|}
\hline Author, Year & No of Patients & Population: Age Range & $\begin{array}{c}\text { Short-Term } \\
\text { Antibiotic Therapy }\end{array}$ & $\begin{array}{c}\text { Long-Term } \\
\text { Antibiotic Therapy }\end{array}$ & $\begin{array}{l}\text { Inclusion Based on Centor } \\
\text { Criteria [72] (Yes/No) }\end{array}$ & Sponsorship \\
\hline Sinanian, 1972 & 154 & NA & Clindamycin 5d & $\begin{array}{l}\text { Clindamycin 10d, } \\
\text { Penicillin V 10d }\end{array}$ & No & $\begin{array}{l}\text { The Upjohn Company, } \\
\text { Michigan }\end{array}$ \\
\hline Gerber, 1987 & 172 & $3-25$ & Penicillin V 5d & Penicillin V 10d & No & No mention of sponsor \\
\hline Strömberg, 1988 & 203 & $7-70$ & Penicillin V 5d & $\begin{array}{l}\text { Penicillin V 10d, } \\
\text { Cefadroxil 10d }\end{array}$ & No & $\begin{array}{l}\text { Bristol-Myers AB. Sweden } \\
\text { and Leo AB Sweden }\end{array}$ \\
\hline Portier, 1990 & 125 & $15-79$ & Cefpodoxime $5 \mathrm{~d}$ & Penicillin V 10d & No & No mention of sponsor \\
\hline Gehanno, 1991 & 170 & $5-70$ & Cefuroxime $4 \mathrm{~d}$ & Penicillin V 10d & No & Glaxo \\
\hline Hooton, 1991 & 241 & NA (only included $\geq 16$ year) & Azithromycin $4 \mathrm{~d}$ & Penicillin V 10d & No & $\begin{array}{l}\text { Pfizer Central Research } \\
\text { Groton, Connecticut }\end{array}$ \\
\hline Milatovic, 1991 & 209 & NA (only included children) & Cefadroxil 5d & Penicillin V 10d & No & No mention of sponsor \\
\hline Hamill, 1993 & 82 & $2-12$ & Azithromycin 3d & Penicillin V 10d & No & No mention of sponsor \\
\hline Muller, 1993 & 144 & NA (only included $\geq 12$ year) & Azithromycin 3d & Clarithromycin 10d & No & No mention of sponsor \\
\hline Weippl, 1993 & 90 & $2-12$ & Azithromycin 3d & Erythromycin 10d & No & No mention of sponsor \\
\hline Peyramond, 1994 & 172 & $8-25$ & Cefixime $4 \mathrm{~d}$ & Penicillin V 10d & No & No mention of sponsor \\
\hline Pichichero, 1994 & 449 & $2-17$ & Cefpodoxime $5 \mathrm{~d}$ & $\begin{array}{l}\text { Cefpodoxime 10d, } \\
\text { Penicillin V 10d }\end{array}$ & No & $\begin{array}{l}\text { The Upjohn Company, } \\
\text { Michigan }\end{array}$ \\
\hline Portier, 1994 & 166 & $11-82$ & Cefpodoxime 5d & Penicillin V 10d & No & Roussel-Uclaf \\
\hline Adam, 1995 & 151 & $1-12$ & Cefixime $5 \mathrm{~d}$ & Penicillin V 10d & No & No mention of sponsor \\
\hline Carbon, 1995 & 190 & $15-79$ & Cefotiam $5 \mathrm{~d}$ & Penicillin V 10d & No & Roussel-Uclaf \\
\hline Portier, 1995 & 262 & $8-30$ & Josamycin $5 \mathrm{~d}$ & Penicillin V 10d & No & No mention of sponsor \\
\hline Adam, 1996 & 201 & $3-17$ & Erythromycin 5d & Penicillin V 10d & No & $\begin{array}{l}\text { Infectopharm Arzneimittel } \\
\text { GmbH, Germany }\end{array}$ \\
\hline Carbon, 1996 & 259 & $18-65$ & $\begin{array}{l}\text { Azithromycin } 3 \\
\text { and } 5 \mathrm{~d}\end{array}$ & Roxithromycin 10d & No & Pfizer France \\
\hline Muller, 1996 & 187 & $15-86$ & Azithromycin 3d & Roxithromycin 10d & No & No mention of sponsor \\
\hline O'Doherty, 1996a & 358 & $2-13$ & $\begin{array}{l}\text { Azithromycin } 3 \mathrm{~d} \\
\quad(2 \text { doses })\end{array}$ & Penicillin V 10d & No & No mention of sponsor \\
\hline O'Doherty, 1996b & 308 & NA (only included $\geq 12$ year) & Azithromycin 3d & Cefaclor 10d & No & No mention of sponsor \\
\hline
\end{tabular}


Table 1. Cont.

\begin{tabular}{|c|c|c|c|c|c|c|}
\hline Author, Year & No of Patients & Population: Age Range & $\begin{array}{c}\text { Short-Term } \\
\text { Antibiotic Therapy }\end{array}$ & $\begin{array}{c}\text { Long-Term } \\
\text { Antibiotic Therapy }\end{array}$ & $\begin{array}{l}\text { Inclusion Based on Centor } \\
\text { Criteria [72] (Yes/No) }\end{array}$ & Sponsorship \\
\hline Pacifico, 1996 & 154 & $3-12$ & Azithromycin 3d & Penicillin V 10d & No & Funded publicly \\
\hline Schaad, 1996 & 320 & $1-14$ & Azithromycin 3d & Penicillin V 10d & No & No mention of sponsor \\
\hline Gendrel, 1997 & 210 & $1-14$ & Spiramycin 5d & Penicillin V 7d & No & Rhone-Poulenc Rorer \\
\hline Tack, 1997 & 440 & $1-18$ & Cefdinir 5d & Penicillin V 10d & No & $\begin{array}{c}\text { Parke-Davis } \\
\text { Pharmaceutical Research }\end{array}$ \\
\hline Cremer, 1998 & 102 & $1-12$ & Azithromycin 3d & Cefaclor 10d & No & No mention of sponsor \\
\hline Garcia Callejo, 1998 & 55 & $3-6$ & Azithromycin 3d & $\begin{array}{c}\text { Amox/clav+Cefaclor } \\
7-14 \mathrm{~d}\end{array}$ & No & No mention of sponsor \\
\hline Mehra, 1998 & 396 & $3-13$ & Cefuroxime $5 \mathrm{~d}$ & Cefuroxime 10d & No & No mention of sponsor \\
\hline Tack, 1998 & 432 & $13-76$ & Cefdinir 5d & Penicillin V 10d & No & $\begin{array}{c}\text { Parke-Davis } \\
\text { pharmaceutical research }\end{array}$ \\
\hline Venuta, 1998 & 137 & $4-12$ & Azithromycin 3d & Clarithromycin 10d & No & No mention of sponsor \\
\hline Adam, 2000 & 4440 & $1-18$ & $\begin{array}{l}\text { Ceftibuten } 5 \mathrm{~d}, \\
\text { Erythromycin } 5 \mathrm{~d}, \\
\text { Cefuroxime } 5 \mathrm{~d}, \\
\text { Clarithromycin } 5 \mathrm{~d}, \\
\text { Loracarbef } 5 \mathrm{~d}, \\
\text { Amox/clav } 5 \mathrm{~d}\end{array}$ & Penicillin V 10d & No & $\begin{array}{c}\text { Cascan, Essex Pharma, } \\
\text { Glaxo Wellcome, } \\
\text { Infectopharm Arzneimittel } \\
\text { und Consilium, Lilly } \\
\text { Deutschland, and Smith } \\
\text { Kline Beecham Pharma }\end{array}$ \\
\hline McCarty, 2000 & 487 & $1-12$ & Clarithromycin 5d & Penicillin V 10d & No & No mention of sponsor \\
\hline Zwart, 2000 & 186 & $15-60$ & Penicillin V 3d & Penicillin V 7d & Yes & Funded publicly \\
\hline Esposito, 2001 & 120 & $3-12$ & Cefaclor 5d & Cefaclor 10d & No & No mention of sponsor \\
\hline Kaplan, 2001 & 392 & $12-61$ & Azithromycin 5d & Clarithromycin 10d & No & Abbott laboratories \\
\hline Norrby, 2001 & 288 & $15-74$ & Telithromycin 5d & Penicillin V 10d & No & Aventis pharma \\
\hline Portier, 2001 & 223 & $3-12$ & Josamycin 5d & Penicillin V 10d & No & Aventis Pharma \\
\hline Cohen, 2002 & 501 & $2-12$ & $\begin{array}{l}\text { Azithromycin 3d } \\
\text { (2 doses) }\end{array}$ & Penicillin V 10d & No & Pfizer France \\
\hline Portier, 2002 & 333 & $12-40$ & Clarithromycin 5d & Penicillin V 10d & No & $\begin{array}{c}\text { Abbott France } \\
\text { (Rungis, France) and } \\
\text { Sanofi-Synthelabo }\end{array}$ \\
\hline
\end{tabular}


Table 1. Cont.

\begin{tabular}{|c|c|c|c|c|c|c|}
\hline Author, Year & No of Patients & Population: Age Range & $\begin{array}{c}\text { Short-Term } \\
\text { Antibiotic Therapy }\end{array}$ & $\begin{array}{c}\text { Long-Term } \\
\text { Antibiotic Therapy }\end{array}$ & $\begin{array}{l}\text { Inclusion Based on Centor } \\
\text { Criteria [72] (Yes/No) }\end{array}$ & Sponsorship \\
\hline Schaad, 2002 & 271 & $2-12$ & Azithromycin 3d & Penicillin V 10d & No & Pfizer AG (PK) \\
\hline Quinn, 2003 & 463 & $13-81$ & Telithromycin $5 \mathrm{~d}$ & Clarithromycin 10d & No & Aventis Pharma \\
\hline Takker, 2003 & 331 & $12-75$ & Clarithromycin $5 \mathrm{~d}$ & Penicillin V 10d & No & Abbott Laboratories \\
\hline Zwart, 2003 & 69 & $4-15$ & Penicillin V 3d & Penicillin V 7d & Yes & Funded publicly \\
\hline Kafetzis, 2004 & 265 & $3-13$ & Cefprozil 5d & $\begin{array}{l}\text { Penicillin V 10d, } \\
\text { Clarithromycin 10d }\end{array}$ & No & No mention of sponsor \\
\hline Norrby, 2004 & 858 & NA (only included $\geq 13$ year) & Telithromycin $5 \mathrm{~d}$ & $\begin{array}{l}\text { Penicillin V 10d, } \\
\text { Clarithromycin 10d }\end{array}$ & No & Aventis Pharma \\
\hline Scholz, 2004 & 1952 & $1-17$ & Cefuroxime $5 \mathrm{~d}$ & Penicillin V 10d & No & No mention of sponsor \\
\hline $\begin{array}{c}\text { Syrogiannopoulos, } \\
2004\end{array}$ & 537 & $2-16$ & $\begin{array}{c}\text { Clarithromycin } 5 \mathrm{~d} \\
\text { (2 doses) } \\
\text { Amox/clav } 5 \mathrm{~d}\end{array}$ & Penicillin V 10d & No & Abbott Laboratories \\
\hline Sakata, 2008 & 231 & $1-16$ & Cefcapene $5 \mathrm{~d}$ & $\begin{array}{l}\text { Cefcapene 10d, } \\
\text { Amoxicillin 10d }\end{array}$ & No & No mention of sponsor \\
\hline Kuroki, 2013 & 96 & $1-13$ & Amox/clav 3d & Amoxicillin 10d & No & Glaxo-SmithKline K.K. \\
\hline Skoog Ståhlgren, 2019 & 422 & $3-67$ & Penicillin V 5d & Penicillin V 10d & Yes & Funded publicly \\
\hline
\end{tabular}




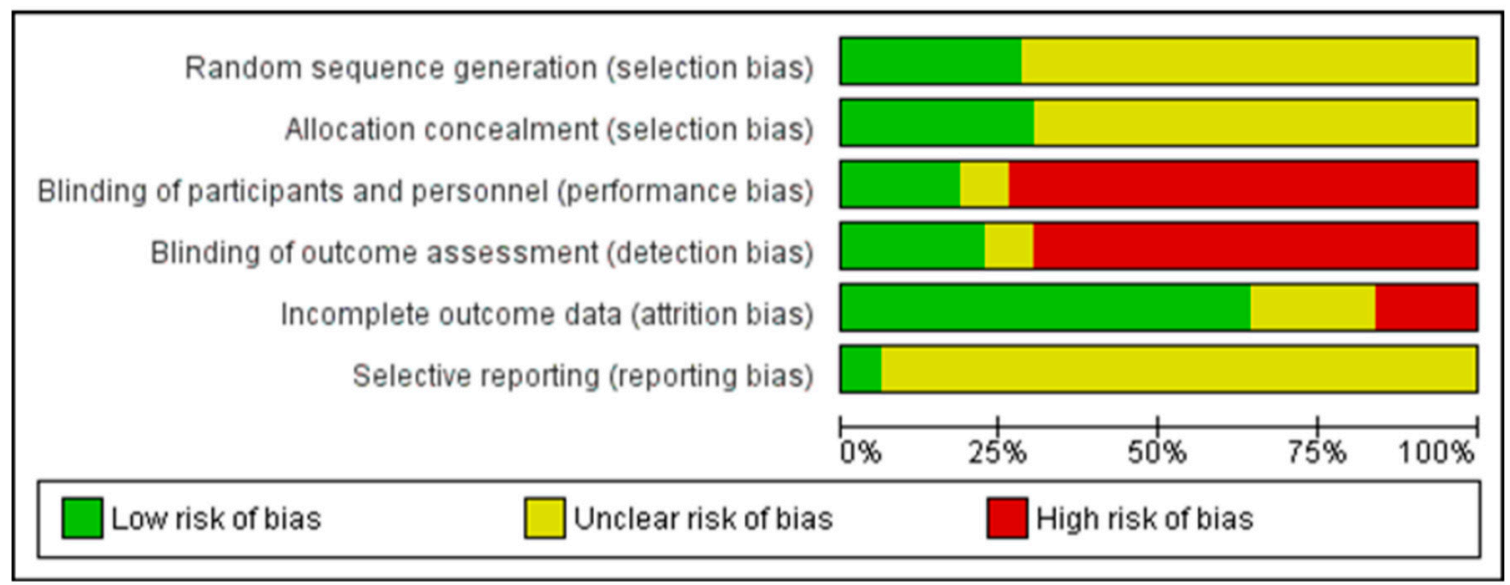

Figure 2. Bias assessment in the included studies. Risks are resented as percentages across different categories of bias. Unclear risk of bias (yellow) refers to studies with lack in systematic reporting of methods and results or when sources of funding were inadequately described. Green refers to low risk of bias; red refers to high risk of bias. Risk of bias: review authors' judgements about each risk of bias item presented as percentages across all included studies. The main reason for unclear is lack of reporting, selective bias was only possible to assess in one trial with the protocol available in clinicaltrials.gov (Bethesda, MD, USA) and in other types of bias the source of funding for the project was unclear.

\subsection{Effects of Intervention}

Primary outcomes: A total of 47 clinical trials reported data on early clinical cure, involving 18,581 patients. Overall, short-term antibiotic therapy was as effective as long antibiotic courses (OR 0.95; 95\% CI, 0.79 to 1.15) (Figure 3). Three studies including 783 patients, which compared short-course penicillin vs. long-course penicillin, favored long-course penicillin for early clinical cure (OR 0.43; 95\% CI, 0.23 to 0.82) (Supplementary Figure S1). Short-term macrolide therapy was as effective as long-term penicillin courses in 17 studies including 5059 patients (OR 0.93; 95\% CI, 0.68 to 1.26) (Supplementary Figure S2). In 11 trials including 4282 patients, short-term cephalosporin therapy was associated with greater odds for clinical cure compared to long-term penicillin therapy (OR 1.48; 95\% CI, 1.11 to 1.96) (Supplementary Figure S3).

Early bacteriological eradication was available in 47 clinical trials, with a total of 17,659 individuals. The overall summary favored long-course therapy, although no statistical difference was observed (OR 0.78; 95\% CI, 0.60 to 1.00). The Supplementary Figures S4-S6 show the following subgroup analyses: (a) short course penicillin was associated with lower bacteriological eradication in comparison to long course penicillin (OR 0.34; $95 \%$ CI, 0.19 to 0.61 ); (b) short-term macrolide therapy was as effective as long-term penicillin regarding early bacteriological eradication (OR 0.76; 95\% CI, 0.48 to 1.20 ); and (c) short-term cephalosporin regimens achieved greater eradication rates compared to long-term penicillin therapy (OR 1.60; 95\% CI, 1.13 to 2.27).

Secondary outcomes: A total of 28 studies, including 11,853 patients reported data on late clinical cure. There was no difference between the two groups (OR 0.91; 95\% CI, 0.80 to 1.04) (Supplementary Figure S7). We observed no association among patients allocated to longer regimens (OR 0.81; $95 \%$ CI, 0.63 to 1.04) (Supplementary Figure S8). Thirty-nine studies reported data on adverse events, including 14,081 patients. Adverse events were observed in $1211(17.7 \%)$ patients assigned to short-term antibiotic regimens (17.7\%), while $893(12.3 \%)$ patients in the group assigned to long-term antibiotic regimens reported adverse events (OR 1.35; 95\% CI, 1.08 to 1.68) (Supplementary Figure S9). However, when different courses of penicillin were compared, more moderate adverse events were observed among patients taking the 10-day course in comparison to the five-day group- $33 \% \mathrm{vs.} 23 \%$, respectively—information only reported in one trial [19]. 


\begin{tabular}{|c|c|c|c|c|c|c|c|c|c|c|c|}
\hline \multirow[b]{2}{*}{ Study or Subgroup } & \multicolumn{2}{|c|}{ Short-term antibiotics } & \multicolumn{2}{|c|}{ Long-term antibiotics } & \multicolumn{3}{|c|}{ Odds Ratio } & \multirow{2}{*}{\multicolumn{4}{|c|}{$\begin{array}{c}\text { Odds Ratio } \\
\text { M-H, Random, } 95 \% \mathrm{Cl}\end{array}$}} \\
\hline & Events & Total & Events & Total & Weight & M-H, Random, $95 \% \mathrm{Cl}$ & Year & & & & \\
\hline Sinanian 1972 & 18 & 22 & 121 & 132 & $1.7 \%$ & $0.41[0.12,1.42]$ & 1972 & & & 1 . & \\
\hline Gerber 1987 & 67 & 73 & 93 & 99 & $1.9 \%$ & $0.72[0.22,2.33]$ & 1987 & & & & \\
\hline Portier 1990 & 65 & 65 & 58 & 60 & $0.3 \%$ & $5.60[0.26,119.01]$ & 1990 & & & & \\
\hline Gehanno 1991 & 89 & 90 & 77 & 80 & $0.6 \%$ & $3.47[0.35,34.02]$ & 1991 & & & & \\
\hline Hooton 1991 & 150 & 151 & 89 & 90 & $0.4 \%$ & $1.69[0.10,27.28]$ & 1991 & & & & \\
\hline Weippl 1993 & 42 & 44 & 45 & 46 & $0.5 \%$ & $0.47[0.04,5.34]$ & 1993 & & & & \\
\hline Muller 1993 & 68 & 71 & 71 & 73 & $0.9 \%$ & $0.64[0.10,3.94]$ & 1993 & & & & \\
\hline Hamill 1993 & 40 & 41 & 41 & 41 & $0.3 \%$ & $0.33[0.01,8.22]$ & 1993 & & & & \\
\hline Pichichero 1994 & 144 & 154 & 277 & 295 & $3.2 \%$ & $0.94[0.42,2.08]$ & 1994 & & & - & \\
\hline Peyramond 1994 & 88 & 91 & 79 & 81 & $0.9 \%$ & $0.74[0.12,4.56]$ & 1994 & & & & \\
\hline Portier 1994 & 85 & 88 & 75 & 78 & $1.1 \%$ & $1.13[0.22,5.79]$ & 1994 & & & & \\
\hline Adam 1995 & 72 & 75 & 74 & 76 & $0.9 \%$ & $0.65[0.11,4.00]$ & 1995 & & & & \\
\hline Portier 1995 & 123 & 130 & 128 & 132 & $1.7 \%$ & $0.55[0.16,1.92]$ & 1995 & & & - & \\
\hline Carbon 1995 & 106 & 119 & 103 & 117 & $3.2 \%$ & $1.11[0.50,2.47]$ & 1995 & & & & \\
\hline Schaad 1996 & 149 & 160 & 143 & 160 & $3.3 \%$ & $1.61[0.73,3.56]$ & 1996 & & & & \\
\hline Muller 1996 & 91 & 91 & 91 & 96 & $0.4 \%$ & $11.00[0.60,201.83]$ & 1996 & & & & \\
\hline ODoherty 1996a & 225 & 226 & 128 & 132 & $0.6 \%$ & $7.03[0.78,63.59]$ & 1996 & & & & \\
\hline ODoherty 1996b & 143 & 152 & 152 & 156 & $1.8 \%$ & $0.42[0.13,1.39]$ & 1996 & & & - & \\
\hline Pacifico 1996 & 65 & 76 & 73 & 78 & $2.1 \%$ & $0.40[0.13,1.23]$ & 1996 & & & & \\
\hline Carbon 1996 & 175 & 176 & 82 & 83 & $0.4 \%$ & $2.13[0.13,34.54]$ & 1996 & & & & \\
\hline Adam 1996 & 100 & 102 & 97 & 99 & $0.8 \%$ & $1.03[0.14,7.47]$ & 1996 & & & & \\
\hline Tack 1997 & 205 & 224 & 196 & 216 & $4.0 \%$ & $1.10[0.57,2.13]$ & 1997 & & - & - & \\
\hline Gendrel 1997 & 98 & 102 & 106 & 108 & $1.0 \%$ & $0.46[0.08,2.58]$ & 1997 & & & & \\
\hline Tack 1998 & 194 & 218 & 181 & 214 & $4.7 \%$ & $1.47[0.84,2.59]$ & 1998 & & & & \\
\hline Venuta 1998 & 73 & 74 & 62 & 63 & $0.4 \%$ & $1.18[0.07,19.22]$ & 1998 & & & & \\
\hline Mehra 1998 & 177 & 201 & 189 & 205 & $4.0 \%$ & $0.62[0.32,1.21]$ & 1998 & & & - & \\
\hline Garcia Callejo 1998 & 24 & 24 & 26 & 31 & $0.4 \%$ & $10.17[0.53,193.67]$ & 1998 & & & & \\
\hline Cremer 1998 & 48 & 51 & 48 & 51 & $1.1 \%$ & $1.00[0.19,5.20]$ & 1998 & & & & \\
\hline Zwart 2000 & 58 & 96 & 79 & 92 & $3.7 \%$ & $0.25[0.12,0.51]$ & 2000 & & & & \\
\hline McCarty 2000 & 244 & 252 & 220 & 235 & $2.9 \%$ & $2.08[0.86,5.00]$ & 2000 & & & & \\
\hline Adam 2000 & 2861 & 3028 & 1319 & 1412 & $7.2 \%$ & $1.21[0.93,1.57]$ & 2000 & & & - & \\
\hline Norrby 2001 & 110 & 138 & 119 & 150 & $4.6 \%$ & $1.02[0.58,1.82]$ & 2001 & & & 一 & \\
\hline Portier 2001 & 103 & 114 & 97 & 109 & $2.9 \%$ & $1.16[0.49,2.75]$ & 2001 & & & & \\
\hline Esposito 2001 & 61 & 61 & 59 & 59 & & Not estimable & 2001 & & & & \\
\hline Kaplan 2001 & 182 & 198 & 178 & 194 & $3.6 \%$ & $1.02[0.50,2.11]$ & 2001 & & & - & \\
\hline Schaad 2002 & 134 & 141 & 126 & 130 & $1.7 \%$ & $0.61[0.17,2.13]$ & 2002 & & & - & \\
\hline Portier 2002 & 156 & 168 & 159 & 165 & $2.4 \%$ & $0.49[0.18,1.34]$ & 2002 & & & & \\
\hline Cohen 2002 & 292 & 334 & 155 & 167 & $4.0 \%$ & $0.54[0.28,1.05]$ & 2002 & & & & \\
\hline Quinn 2003 & 193 & 232 & 192 & 231 & $5.3 \%$ & $1.01[0.62,1.64]$ & 2003 & & & - & \\
\hline Takker 2003 & 174 & 177 & 145 & 154 & $1.6 \%$ & $3.60[0.96,13.55]$ & 2003 & & & & \\
\hline Scholz 2004 & 481 & 496 & 1357 & 1456 & $4.8 \%$ & $2.34[1.35,4.07]$ & 2004 & & & $\longrightarrow$ & \\
\hline Syrogiannopoulos 2004 & 384 & 402 & 132 & 135 & $1.7 \%$ & $0.48[0.14,1.67]$ & 2004 & & & - & \\
\hline Norrby 2004 & 363 & 430 & 361 & 428 & $6.3 \%$ & $1.01[0.70,1.45]$ & 2004 & & & - & \\
\hline Kafetzis 2004 & 87 & 88 & 174 & 177 & $0.6 \%$ & $1.50[0.15,14.63]$ & 2004 & & & & \\
\hline Sakata 2008 & 80 & 80 & 151 & 151 & & Not estimable & 2008 & & & & \\
\hline Kuroki 2013 & 54 & 54 & 41 & 42 & $0.3 \%$ & $3.94[0.16,99.20]$ & 2013 & & & & \\
\hline Skoog Stăhlgren 2019 & 190 & 212 & 197 & 210 & $3.7 \%$ & $0.57[0.28,1.16]$ & 2019 & & & {[} & \\
\hline Total $(95 \% \mathrm{Cl})$ & & 9792 & & 8789 & $100.0 \%$ & $0.95[0.79,1.15]$ & & & & & \\
\hline Total events & 9131 & & 8166 & & & & & & & & \\
\hline $\begin{array}{l}\text { Heterogeneity: } \operatorname{Tau}^{2}=0.1 \\
\text { Test for overall effect: } Z=\end{array}$ & $\begin{array}{l}C h i^{2}=68.20, \\
50(P=0.62)\end{array}$ & $4(P=0$ & $0.01) ; z^{2}=35 \%$ & & & & & 0.0 & $\begin{array}{c}0.1 \\
\text { Favours long-ter }\end{array}$ & $\begin{array}{cc}10 \\
1 \\
\text { Favours short-term }\end{array}$ & 100 \\
\hline
\end{tabular}

Figure 3. Early clinical cure of short-term antibiotic therapy compared to long-term regimen treatment.

\section{Discussion}

\subsection{Summary of Main Results}

A total of 50 randomized clinical trials were included in this article, constituting the most comprehensive and extensive systematic review of only randomized clinical trials published to date in patients with streptococcal pharyngitis. Most of the trials included in this review evaluated the effectiveness of short-course broad spectrum antibiotics (i.e., macrolides and cephalosporins), compared with a long course of the narrow spectrum antibiotic (penicillin V). Subgroup analysis demonstrated important differences regarding the effectiveness for early clinical cure and early microbiological cure depending on the antibiotic groups included in the comparison: (a) short-course penicillin was less effective when compared to long-course penicillin $\mathrm{V}$; (b) short-course macrolides were equally effective when compared to long-course penicillin $\mathrm{V}$; (c) short-course cephalosporins were more effective when compared to long-course penicillin V.

\subsection{Strengths and Weaknesses of Study}

The greatest strength of this review was our comprehensive search strategy. To our knowledge, this is the most comprehensive systematic review evaluating short- vs. long-course antibiotic therapy for streptococcal pharyngitis. Eight systematic reviews have been published to date [11-18]. These reviews include fewer clinical trials compared to our review, with a range of five to 22 studies. We used a 
broader search string to increase the sensitivity of the search and hand-searched reference lists of all these reviews to identify studies fulfilling our inclusion criteria. Another strength was the inclusion of papers in which confirmation of streptococcal infection was a requirement to be included in the study, then homogenizing the type of population these findings can be applied to.

The greatest weakness is the broad definition of inclusion criteria, hence including papers with high risk of bias, and grouping for meta-analysis papers comparing different types, length and doses of antibiotics. In the quality assessment, we found great weaknesses in the 50 studies. A total of 40 of the included studies had high risk of bias regarding blinding of participants (i.e., no blinding of patients, personnel and evaluators). These patients may be influenced by the investigator's description of the trial. At the same time, the patients who agreed to participate could potentially have a more positive attitude towards a shorter and alternative treatment than the longer standard regimen. This could furthermore have influenced the patient's own perception of subjective symptoms in the clinical evaluation and caused a systematic reporting bias. Problems in the blinding of the investigators could have influenced choice of treatment, and hence causing selection bias. Another major limitation is the high risk of publication bias.

It is problematic to group for meta-analysis studies comparing different doses. For example, five clinical trials compared short- vs. long-course penicillin $\mathrm{V}$ regimens, with daily doses ranging from 750 to $3200 \mathrm{mg}$. The pooled effect of short-term penicillin therapy on clinical cure showed a lower effectiveness compared with standard penicillin courses. For adults and teenagers, Gerber et al. [25] used $250 \mathrm{mg}$ t.i.d. for 5 or 10 days; Strömberg et al. [26] $800 \mathrm{mg}$ b.i.d. for 5 and 10 days; Zwart et al. [55,65] $500 \mathrm{mg}$ t.i.d. for 3 or 7 days; and Skoog-Ståhlgren et al. [19] used $800 \mathrm{mg}$ q.i.d. for five days in the experimental group and $1 \mathrm{~g}$ t.i.d. for 10 days in the control group. The use of such different doses of penicillin could explain the differences in the results observed in these studies as the effectiveness of $\beta$ lactam antibiotics is dependent on time above the minimum inhibitory concentration [73]. We only included studies assessing short treatment regimens up to five days. Because of this, two studies, which compared amoxicillin six-day therapies to penicillin ten-day treatment, were excluded [74,75]. Finally, we only retrieved studies carried out in high income countries, making it more difficult to generalize to a worldwide setting, specifically those settings with high prevalence of rheumatic fever caused by GAS. Rheumatic fever remains a widespread disease all over the world, resulting in high morbidity and preventable early deaths in lower- and middle-income countries. Adequate and timely therapy could potentially prevent rheumatic heart disease [76].

\subsection{Comparison with Previous Studies}

Falagas et al. [18] assessed 11 trials comparing short- vs. long-course antibiotic treatment in patients with streptococcal pharyngitis/tonsillitis through a meta-analysis in 2008. They included studies comparing the same drug, in the same daily dosage, but for different durations. The review concluded that shorter courses of antibiotics, especially with penicillin $\mathrm{V}$, had lower eradication rates than standard 10-day treatment. However, they did not find strong evidence for the best length of treatment. In response to this study, Dawson-Hahn et al. [16] suggested that we should shorten antibiotic treatment for common bacterial infections in outpatient settings. They also accentuated that shorter courses should be common practice in most other respiratory infections, such as pneumonia and acute bacterial sinusitis, but that currently, there was no clear evidence for shorter courses of penicillin for streptococcal pharyngitis. The meta-analysis by Altamimi et al. [15] from 2012 examined 20 trials comparing short- vs. long-course penicillin regimens in treating GAS pharyngitis in children. They found a comparable efficacy of the short duration (three to six days) treatment compared to penicillin $\mathrm{V}$ therapy for 10 days regarding clinical cure. Similar results were observed in a more recent review with the inclusion of 22 clinical trials [17].

The controversial results observed with all types of antibiotics were also observed with the cephalosporins. On one hand, in one meta-analysis published in 2007, the authors found that short-course cephalosporin treatment was as effective as long penicillin therapy regarding clinical 
cure; however, they raised the question whether such critical important antibiotics should be used on an infection as GAS pharyngotonsillitis as antimicrobial resistance is a growing concern [14]. On the other hand, in another review published two years earlier, cephalosporins were found to be more effective than long courses of penicillin to achieve early clinical cure, as we have also demonstrated in this review [12]. Another review published by the same authors found that short-term azithromycin courses were as effective as long-term penicillin treatment [13].

Finally, a Cochrane review published in 2016, which included trials based on type of antibiotics instead of length of treatment in patients with streptococcal pharyngitis concluded that penicillin should be the preferred first choice treatment for pharyngitis caused by GAS in both children and adults [77].

\subsection{Relevance of the Study}

The results of this review are highly relevant in clinical practice worldwide. For many years, the use of shorter courses of broad-spectrum antibiotics has been advocated as the right strategy to overcome the problems of treatment compliance without considering the harms regarding mild to moderate adverse events and the role of broad-spectrum antibiotics in the development of antimicrobial resistance.

Currently, the US Food and Drug Administration has approved cefdinir, cefpodoxime and azithromycin for a 5-day course of therapy for GAS pharyngitis. Macrolides and cephalosporins are considered as critically important antimicrobials for human medicine by the World Health Organization and should be reserved when the first-line choice fails [78]. In line with the recently released aware list [79], the first line option should be narrow-spectrum antibiotic such as penicillin $\mathrm{V}$ instead of broad-spectrum antibiotics such as azithromycin and $3^{\text {rd }}$ generation cephalosporines. Therefore, critically important antibiotics or antibiotics belonging to the watch group of the aware list should be used to a minimum in primary care in order to prevent development of antimicrobial resistance.

The findings of this review are highly relevant for funding future research addressing the optimization of the use of antibiotics in primary care. First of all, it should be discussed whether research including the use of critically important antibiotics should be funded and carried out in primary care. Not only could it be seen as unethical to use resources on comparing antibiotics that should not be used in primary care but also due to the higher risk of adverse events when exposed to the patients and development of antimicrobial resistance.

Finally, these findings showed the scarcity of available studies comparing only penicillin length and doses. Meta-analyses depend on the availability of high quality and homogeneous data to draw robust conclusions. Hence, future research should focus on executing trials that assess the effectiveness of different doses and lengths of penicillin across different contexts.

\section{Conclusions}

Macrolides and cephalosporins belong to the list of "Highest Priority Critically Important Antimicrobials"; hence, long-course penicillin V should remain as the first line antibiotic for the management of patients with streptococcal pharyngitis as far as the benefits of using these two types of antibiotics do not outweigh the harms of their unnecessary use.

Supplementary Materials: The following are available online at http://www.mdpi.com/2079-6382/9/11/733/s1, Figure S1: Early clinical cure of short-term penicillins compared to long-term penicillin therapy. Figure S2: Early clinical cure of short-term macrolides compared to long-term penicillin therapy. Figure S3: Early clinical cure of short-term cephalosporins compared to long-term penicillin therapy Figure S4: Early bacteriological eradication of short-term penicillins compared to long-term penicillin therapy. Figure S5: Early bacteriological eradication of short-term macrolides compared to long-term penicillin therapy. Figure S6: Early bacteriological eradication of short-term cephalosporins compared to long-term penicillin therapy. Figure S7: Late clinical cure of short-term antibiotic therapy compared to long-term regimen treatment. Figure S8: Late bacteriological eradication of short-term antibiotic therapy compared to long-term regimen treatment. Figure S9: Adverse effects of short-term antibiotic therapy compared to long-term antibiotic therapy. 
Author Contributions: A.E.H.: study design, data analysis, data interpretation and writing; C.L.: study design, data analysis, data interpretation and writing; L.B.: critical review of the manuscript; G.C.: study design, data analysis, data interpretation and writing. All authors have read and agreed to the published version of the manuscript.

Funding: This research received no external funding.

Conflicts of Interest: The authors declare no conflict of interest.

\section{References}

1. Schappert, S.M.; Rechtsteiner, E.A. Ambulatory medical care utilization estimates for 2006. Natl. Health Stat. Rep. 2008, 8, 1-29.

2. Fleming-Dutra, K.E.; Hersh, A.L.; Shapiro, D.J.; Bartoces, M.; Enns, E.A.; File, T.M.; Finkelstein, J.A.; Gerber, J.S.; Hyun, D.Y.; Linder, J.A.; et al. Prevalence of Inappropriate Antibiotic Prescriptions among US Ambulatory Care Visits, 2010-2011. JAMA 2016, 315, 1864-1873. [CrossRef] [PubMed]

3. Spinks, A.; Glasziou, P.P.; Del Mar, C.B. Antibiotics for sore throat. Cochrane Database Syst. Rev. 2013, 2013, CD000023. [CrossRef] [PubMed]

4. Shulman, S.T.; Bisno, A.L.; Clegg, H.W.; Gerber, M.A.; Kaplan, E.L.; Lee, G.; Martin, J.M.; van Beneden, C. Clinical practice guideline for the diagnosis and management of group A streptococcal pharyngitis: 2012 update by the Infectious Diseases Society of America. Clin Infect. Dis. 2012, 55, 1279-1282. [CrossRef] [PubMed]

5. Pelucchi, C.; Grigoryan, L.; Galeone, C.; Esposito, S.; Huovinen, P.; Little, P.; Verheij, T. Guideline for the management of acute sore throat. Clin. Microbiol. Infect. 2012, 18, 1-27. [CrossRef]

6. Spellberg, B.; Rice, L.B. Duration of Antibiotic Therapy: Shorter Is Better. Ann. Intern. Med. 2019, 171, 210-211. [CrossRef]

7. Matthys, J.; De Meyere, M.; Van Driel, M.L.; De Sutter, A. Differences Among International Pharyngitis Guidelines: Not Just Academic. Ann. Fam. Med. 2007, 5, 436-443. [CrossRef]

8. The European Committee on Antimicrobial Susceptibility Testing. Available online: https://www.eucast.org/ (accessed on 12 October 2020).

9. Feder, H.M.; Gerber, M.A.; Randolph, M.F.; Stelmach, P.S.; Kaplan, E.L. Once-Daily Therapy for Streptococcal Pharyngitis with Amoxicillin. Pediatrics 1999, 103, 47-51. [CrossRef]

10. Lennon, D.R.; Farrell, E.; Martin, D.R.; Stewart, J.M. Once-daily amoxicillin versus twice-daily penicillin V in group A beta-haemolytic streptococcal pharyngitis. Arch. Dis. Child. 2008, 93, 474-478. [CrossRef]

11. Ioannidis, J.P.A.; Contopoulos-Ioannidis, D.G.; Chew, P.; Lau, J. Meta-analysis of randomized controlled trials on the comparative efficacy and safety of azithromycin against other antibiotics for upper respiratory tract infections. J. Antimicrob. Chemother. 2001, 48, 677-689. [CrossRef]

12. Casey, J.R.; Pichichero, M.E. Metaanalysis of Short Course Antibiotic Treatment for Group A Streptococcal Tonsillopharyngitis. Pediatr. Infect. Dis. J. 2005, 24, 909-917. [CrossRef] [PubMed]

13. Casey, J.R.; Pichichero, M.E. Higher Dosages of Azithromycin Are More Effective in Treatment of Group A Streptococcal Tonsillopharyngitis. Clin. Infect. Dis. 2005, 40, 1748-1755. [CrossRef] [PubMed]

14. Pichichero, M.E.; Casey, J.R. Bacterial eradication rates with shortened courses of 2nd- and 3rd-generation cephalosporins versus 10 days of penicillin for treatment of group A streptococcal tonsillopharyngitis in adults. Diagn. Microbiol. Infect. Dis. 2007, 59, 127-130. [CrossRef] [PubMed]

15. Altamimi, S.; Khalil, A.; Khalaiwi, K.A.; Milner, R.A.; Pusic, M.V.; Al Othman, M.A. Short-term late-generation antibiotics versus longer term penicillin for acute streptococcal pharyngitis in children. Cochrane Database Syst. Rev. 2012, 8, CD004872. [CrossRef]

16. Dawson-Hahn, E.E.; Mickan, S.; Onakpoya, I.; Roberts, N.; Kronman, M.; Butler, C.C.; Thompson, M.J. Short-course versus long-course oral antibiotic treatment for infections treated in outpatient settings: A review of systematic reviews. Fam. Pr. 2017, 34, 511-519. [CrossRef]

17. Rojas-Ramírez, C.; Kramer-Urrutia, T.; Cifuentes, L.; Ram, R.-; Kramer-Urrutia, T. Is a short-course antibiotic treatment effective for streptococcal tonsillopharyngitis in children? Medwave 2017, 17, e6873. [CrossRef]

18. Falagas, M.; Vouloumanou, E.K.; Matthaiou, D.K.; Kapaskelis, A.M.; Karageorgopoulos, D.E. Effectiveness and safety of short-course vs long-course antibiotic therapy for group a beta hemolytic streptococcal tonsillopharyngitis: A meta-analysis of randomized trials. Mayo Clin. Proc. 2008, 83, 880-889. [CrossRef] 
19. Ståhlgren, G.S.; Tyrstrup, M.; Edlund, C.; Giske, C.G.; Mölstad, S.; Norman, C.; Rystedt, K.; Sundvall, P.-D.; Hedin, K. Penicillin V four times daily for five days versus three times daily for 10 days in patients with pharyngotonsillitis caused by group A streptococci: Randomised controlled, open label, non-inferiority study. BMJ 2019, 367, 15337. [CrossRef]

20. Montori, V.M.; Wilczynski, N.L.; Morgan, D.; Haynes, R.B. Optimal search strategies for retrieving systematic reviews from Medline: Analytical survey. BMJ 2004, 330, 68. [CrossRef]

21. Sterne, J.A.C.; Savović, J.; Page, M.J.; Elbers, R.G.; Blencowe, N.S.; Boutron, I.; Cates, C.J.; Cheng, H.-Y.; Corbett, M.S.; Eldridge, S.M.; et al. RoB 2: A revised tool for assessing risk of bias in randomised trials. BMJ 2019, 366, 14898. [CrossRef]

22. Kannan, S.; Gowri, S. Clinical trials in allied medical fields: A cross-sectional analysis of World Health Organization International Clinical Trial Registry Platform. J. Ayurveda Integr. Med. 2016, 7, 48-52. [CrossRef] [PubMed]

23. Review Manager (RevMan) [Computer Program]. Version 5.3. Copenhagen: The Nordic Cochrane Centre, The Cochrane Collaboration. 2014. Available online: https:/training.cochrane.org/online-learning/coresoftware-cochrane-reviews/revman (accessed on 12 October 2020).

24. Sinanian, R.; Ruoff, G.; Panzer, J.; Atkinson, W. Streptococcal pharyngitis: A comparison of the eradication of the organism by 5 and 10-day antibiotic therapy. Curr. Ther. Res. 1972, 14, 716-720.

25. Gerber, M.A.; Randolph, M.F.; Chanatry, J.; Wright, L.L.; De Meo, K.; Kaplan, E.L. Five vs Ten Days of Penicillin V Therapy for Streptococcal Pharyngitis. Arch. Pediatr. Adolesc. Med. 1987, 141, 224-227. [CrossRef]

26. Strömberg, A.; Schwan, A.; Cars, O. Five versus ten days treatment of group A streptococcal pharyngotonsillitis: A randomized controlled clinical trial with phenoxymethyl-penicillin and cefadroxil. Scand. J. Infect. Dis. 1988, 20, 37-46. [CrossRef] [PubMed]

27. Portier, H.; Chavanet, P.; Gouyon, J.B.; Guetat, F. Five day treatment of pharyngotonsillitis with cefpodoxime proxetil. J. Antimicrob. Chemother. 1990, 26, 79-85. [CrossRef]

28. Gehanno, P.; Chiche, D. Traitement des angines à streptocoque bêta hémolytique du groupe A par le céfuroxime axétil pendant 4 jours: Étude comparative à la pénicilline V pendant 10 jours. Méd. Mal. Infect. 1991, 21, 66-70. [CrossRef]

29. Hooton, T.M. A comparison of azithromycin and penicillin $\mathrm{V}$ for the treatment of streptococcal pharyngitis. Am. J. Med. 1991, 91, S23-S26. [CrossRef]

30. Milatovic, D. Evaluation of cefadroxil, penicillin and erythromycin in the treatment of streptococcal tonsillopharyngitis. Pediatr. Infect. Dis. J. 1991, 10, S61-S63. [CrossRef]

31. Hamill, J. Multicentre evaluation of azithromycin and penicillin V in the treatment of acute streptococcal pharyngitis and tonsillitis in children. J. Antimicrob. Chemother. 1993, 31, 89-94. [CrossRef]

32. Müller, O. Comparison of azithromycin versus clarithromycin in the treatment of patients with upper respiratory tract infections. J. Antimicrob. Chemother. 1993, 31, 137-146. [CrossRef]

33. Weippl, G. Multicentre comparison of azithromycin versus erythromycin in the treatment of paediatric pharyngitis or tonsillitis caused by group A streptococci. J. Antimicrob. Chemother. 1993, 31, 95-101. [CrossRef] [PubMed]

34. Peyramond, D.; Tigaud, S.; Bremard-Oury, C.; Scheimberg, A. Multicenter comparative trial of cefixime and phenoxymethylpenicillin for group a beta-hemolytic streptococcal tonsillitis. Curr. Ther. Res. 1994, 55, $14-21$. [CrossRef]

35. Pichichero, M.E.; Gooch, W.M.; Rodriguez, M.; Blumer, J.L.; Aronoff, S.C.; Jacobs, R.F.; Musser, J.M. Effective short-course treatment of acute group A beta-hemolytic streptococcal tonsillopharyngitis. Arch. Pediatr. Adolesc. Med. 1994, 148, 1053-1060. [CrossRef] [PubMed]

36. Portier, H.; Chavanet, P.; Waldner-Combernoux, A.; Kisterman, J.P.; Grey, P.C.; Ichou, F.; Safran, C. Five versus Ten Days Treatment of Streptococcal Pharyngotonsillitis: A Randomized Controlled Trial Comparing Cefpodoxime Proxetil and Phenoxymethyl Penicillin. Scand. J. Infect. Dis. 1994, 26, 59-66. [CrossRef]

37. Adam, D.; Hostalk, U.; Troster, K. Five-day cefixime therapy for bacterial pharyngitis and/or tonsillitis: Comparison with 10-day penicillin V therapy. Infection 1995, 23 (Suppl. S2), S83-S86. [CrossRef] [PubMed]

38. Carbon, C.; Chatelin, A.; Bingen, E.; Zuck, P.; Rio, Y.; Guetat, F.; Orvain, J. A double-blind randomized trial comparing the efficacy and safety of a 5-day course of cefotiam hexetil with that of a 10-day course of penicillin $\mathrm{V}$ in adult patients with pharyngitis caused by group A beta-haemolytic streptococci. J. Antimicrob. Chemother. 1995, 35, 843-854. [CrossRef] [PubMed] 
39. Portier, H.; Lucht, F.; Lescale, O.; Kazmierczak, A.; Ros, A.; Scheimberg, A. Josamycine 5 jours versus penicilline $\mathrm{V} 10$ jours dans le traitement des angines aigues a streptocoque $\beta$-hemolytique du groupe A. Med. Mal. Infect. 1995, 25, 1005-1010. [CrossRef]

40. Adam, D.; Scholz, H.; Aspe, C.; Berzel, H.G.; Bulle, D.; Fritz, H.P.; Grosse, V.; Hartmann, W.; Heil, R.P.; Hirschbrunn, P.; et al. Five days of erythromycin estolate versus ten days of penicillin V in the treatment of group a streptococcal tonsillopharyngitis in children. Eur. J. Clin. Microbiol. Infect. Dis. 1996, 15, 712-717. [CrossRef]

41. Müller, O. An open comparative study of azithromycin and roxithromycin in the treatment of acute upper respiratory tract infections. J. Antimicrob. Chemother. 1996, 37, 83-92. [CrossRef]

42. O'Doherty, B.; Pilfors, G.; Quinn, P.T.; Howard, A.; Bradbury, F.; Scully, M.; Clarke, O.; Kiernan, J.; Ryan, M.F.; O'Kelly, P.; et al. Azithromycin versus penicillin V in the treatment of paediatric patients with acute streptococcal pharyngitis/tonsillitis. Eur. J. Clin. Microbiol. Infect. Dis. 1996, 15, 718-724. [CrossRef]

43. O'Doherty, B. An open comparative study of azithromycin versus cefaclor in the treatment of patients with upper respiratory tract infections. J. Antimicrob. Chemother. 1996, 37, 71-81. [CrossRef] [PubMed]

44. Pacifico, L.; Scopetti, F.; Ranucci, A.; Pataracchia, M.; Savignoni, F.; Chiesa, C. Comparative efficacy and safety of 3-day azithromycin and 10-day penicillin V treatment of group A beta-hemolytic streptococcal pharyngitis in children. Antimicrob. Agents Chemother. 1996, 40, 1005-1008. [CrossRef] [PubMed]

45. Schaad, U.; Heynen, G. Evaluation of the efficacy, safety and toleration of azithromycin vs penicillin V in the treatment of acute streptococcal pharyngitis in children: Results of multicenter, open comparative study. The Swiss Tonsillopharyngitis Study Group. Pediatr. Infect. Dis. J. 1996, 15, 791-795. [CrossRef]

46. Gendrel, D.; Bourrillon, A.; Touron, D.; Lilienthal, F.; Gendrel, D.; Bingen, E.; Raymond, J. Five-Day Spiramycin vs Seven-Day Penicillin V in the Treatment of Streptococcal Tonsillitis in Children. Clin. Drug Investig. 1997, 13, 338-344. [CrossRef]

47. Tack, K.J.; Hedrick, J.A.; Rothstein, E.; Nemeth, M.A.; Keyserling, C.; Pichichero, M.E. A Study of 5-Day Cefdinir Treatment for Streptococcal Pharyngitis in Children. Arch. Pediatr. Adolesc. Med. 1997, 151, 45. [CrossRef]

48. Cremer, J.; Wallrauch, C.; Milatovic, D.; Braveny, I. Azithromycin versus cefaclor in the treatment of pediatric patients with acute group A beta-hemolytic streptococcal tonsillopharyngitis. Eur. J. Clin. Microbiol. Infect. Dis. 1998, 17, 235-239. [CrossRef]

49. García Callejo, F.J.; Velert Vila, M.M.; Orts Alborch, M.H.; Pardo Mateu, L.; Esparcia Navarro, M. Comparación de azitromicina, amoxicilina/ácido clavulánico y cefaclor en el tratamiento de la infección aguda otorrinolaringológica. Acta Otorrinolaringol. Esp. 1998, 49, 306-312.

50. Mehra, S.; Van Moerkerke, M.; Welck, J.; Sverrisson, G.; Sirotiakova, J.; Marr, C.; Staley, H. Short course therapy with cefuroxime axetil for group A streptococcal tonsillopharyngitis in children. Pediatr. Infect. Dis. J. 1998, 17, 452-457. [CrossRef]

51. Tack, K.J.; Henry, D.C.; Gooch, W.M.; Brink, D.N.; Keyserling, C.H. The Cefdinir Pharyngitis Study Group Five-Day Cefdinir Treatment for Streptococcal Pharyngitis. Antimicrob. Agents Chemother. 1998, 42, 1073-1075. [CrossRef]

52. Venuta, A.; Laudizi, L.; Beverelli, A.; Bettelli, F.; Milioli, S.; Garetti, E. Azithromycin Compared with Clarithromycin for the Treatment of Streptococcal Pharyngitis in Children. J. Int. Med Res. 1998, 26, 152-158. [CrossRef]

53. Adam, D.; Scholz, H.; Helmerking, M. Short-Course Antibiotic Treatment of 4782 Culture-Proven Cases of Group A Streptococcal Tonsillopharyngitis and Incidence of Poststreptococcal Sequelae. J. Infect. Dis. 2000, 182, 509-516. [CrossRef] [PubMed]

54. Mccarty, J.; Hedrick, J.A.; Gooch, W.M. Clarithromycin suspension vs penicillin V suspension in children with streptococcal pharyngitis. Adv. Ther. 2000, 17, 14-26. [CrossRef] [PubMed]

55. Zwart, S.; Sachs, A.P.E.; Ruijs, G.J.H.M.; Gubbels, J.W.; Hoes, A.W.; De Melker, R.A. Penicillin for acute sore throat: Randomised double blind trial of seven days versus three days treatment or placebo in adults. BMJ 2000, 320, 150-154. [CrossRef]

56. Esposito, S.; Noviello, S.; Ianniello, F.; D’Errico, G. Short-course therapy with cefaclor for treatment of streptococcal pharyngotonsillitis. Int. J. Antimicrob. Agents 2001, 18, 341-345. [CrossRef] 
57. Kaplan, E.L.; Gooch, W.M.; Notario, G.F.; Craft, J.C. Macrolide Therapy of Group A Streptococcal Pharyngitis: 10 Days of Macrolide Therapy (Clarithromycin) Is More Effective in Streptococcal Eradication than 5 Days (Azithromycin). Clin. Infect. Dis. 2001, 32, 1798-1802. [CrossRef]

58. Norrby, S.R.; Rabie, W.J.; Bacart, P.; Mueller, O.; Leroy, B.; Rangaraju, M.; Butticaz-Iroudayassamy, E. Efficacy of Short-course Therapy with the Ketolide Telithromycin Compared with 10 Days of Penicillin V for the Treatment of Pharyngitis/Tonsillitis. Scand. J. Infect. Dis. 2001, 33, 883-890. [CrossRef]

59. Portier, H.; Bourrillon, A.; Lucht, F.; Choutet, P.; Gehanno, P.; Meziane, L.; Bingen, E. Traitement des angines aiguës à streptocoque $\beta$-hémolytique du groupe $\mathrm{A}$ chez l'enfant par la josamycine pendant cinq jours. Arch. Pédiatr. 2001, 8, 700-706. [CrossRef]

60. Cohen, R.; Reinert, P.; De La Rocque, F.; Levy, C.; Boucherat, M.; Robert, M.; Navel, M.; Brahimi, N.; Deforche, D.; Palestro, B.; et al. Comparison of two dosages of azithromycin for three days versus penicillin V for ten days in acute group A streptococcal tonsillopharyngitis. Pediatr. Infect. Dis. J. 2002, 21, 297-303. [CrossRef]

61. Portier, H.; Filipecki, J.; Weber, F.; Goldfarb, G.; Lethuaire, D.; Chauvin, J.P. Five day clarithromycin modified release versus 10 day penicillin $\mathrm{V}$ for group A streptococcal pharyngitis: A multi-centre, open-label, randomized study. J. Antimicrob. Chemother. 2002, 49, 337-344. [CrossRef] [PubMed]

62. Schaad, U.B.; Kellerhals, P.; Altwegg, M. Azithromycin versus penicillin V for treatment of acute group A streptococcal pharyngitis. Pediatr. Infect. Dis. J. 2002, 21, 304-308. [CrossRef] [PubMed]

63. Quinn, J.; Ruoff, G.E.; Ziter, P.S. Efficacy and tolerability of 5-day, once-daily telithromycin compared with 10-day, twice-daily clarithromycin for the treatment of group A beta-hemolytic streptococcal tonsillitis/pharyngitis: A multicenter, randomized, double-blind, parallel-group study. Clin. Ther. 2003, 25, 422-443. [CrossRef]

64. Takker, U.; Dzyublyk, O.; Busman, T.; Notario, G.F. Comparison of 5 days of extended-release clarithromycin versus 10 days of penicillin $\mathrm{V}$ for the treatment of streptococcal pharyngitis/tonsillitis: Results of a multicenter, double-blind, randomized study in adolescent and adult patients. Curr. Med Res. Opin. 2003, 19, 421-429. [CrossRef] [PubMed]

65. Zwart, S.; Rovers, M.M.; A De Melker, R.; Hoes, A.W. Penicillin for acute sore throat in children: Randomised, double blind trial. BMJ 2003, 327, 1324. [CrossRef] [PubMed]

66. Kafetzis, D.; Liapi, G.; Tsolia, M.; Aoudi, H.; Mathioudakis, J.; Paraskakis, I.; Bairamis, T. Failure to eradicate Group A beta-haemolytic streptococci (GABHS) from the upper respiratory tract after antibiotic treatment. Int. J. Antimicrob. Agents 2004, 23, 67-71. [CrossRef]

67. Norrby, S.R.; Quinn, J.; Rangaraju, M.; Leroy, B. Evaluation of 5-day therapy with telithromycin, a novel ketolide antibacterial, for the treatment of tonsillopharyngitis. Clin. Microbiol. Infect. 2004, 10, 615-623. [CrossRef]

68. Scholz, H. Streptococcal-A Tonsillopharyngitis: A 5-Day Course of Cefuroxime Axetil versus a 10-Day Course of Penicillin V. Chemotherapy 2004, 50, 51-54. [CrossRef]

69. Syrogiannopoulos, G.A.; Bozdogan, B.; Grivea, I.N.; Ednie, L.M.; Kritikou, D.I.; Katopodis, G.D.; Beratis, N.G.; Appelbaum, P.C. Hellenic Antibiotic-Resistant Respiratory Pathogens Study Group. Two dosages of clarithromycin for five days, amoxicillin/clavulanate for five days or penicillin $\mathrm{V}$ for ten days in acute group A streptococcal tonsillopharyngitis. Pediatr. Infect. Dis. J. 2004, 23, 857-865. [CrossRef]

70. Sakata, H. Comparative study of 5-day cefcapene-pivoxil and 10-day amoxicillin or cefcapene-pivoxil for treatment of group A streptococcal pharyngitis in children. J. Infect. Chemother. 2008, 14, 208-212. [CrossRef]

71. Kuroki, H.; Ishiwada, N.; Inoue, N.; Ishikawa, N.; Suzuki, H.; Himi, K.; Kurosaki, T. Comparison of clinical efficacy between 3-day combined clavulanate/amoxicillin preparation treatment and 10-day amoxicillin treatment in children with pharyngolaryngitis or tonsillitis. J. Infect. Chemother. 2013, 19, 12-19. [CrossRef]

72. Centor, R.M.; Witherspoon, J.M.; Dalton, H.P.; Brody, C.E.; Link, K. The Diagnosis of Strep Throat in Adults in the Emergency Room. Med. Decis. Mak. 1981, 1, 239-246. [CrossRef]

73. Turnidge, J.D. The pharmacodynamics of beta-lactams. Clin. Infect. Dis. 1998, 27, 10-22. [CrossRef]

74. Peyramond, D.; Portier, H.; Geslin, P.; Cohen, R. 6-day amoxicillin versus 10-day penicillin V for group A beta-haemolytic streptococcal acute tonsillitis in adults: A French multicentre, open-label, randomized study. The French Study Group Clamorange. Scand. J. Infect. Dis. 1996, 28, 497-501. [CrossRef] [PubMed] 
75. Cohen, R.; Levy, C.; Doit, C.; De La Rocque, F.; Boucherat, M.; Fitoussi, F.; Langue, J.; Bingen, E. Six-day amoxicillin vs. ten-day penicillin V therapy for group A streptococcal tonsillopharyngitis. Pediatr. Infect. Dis. J. 1996, 15, 678-682. [CrossRef]

76. Carapetis, J.R.; Steer, A.C.; Mulholland, E.K.; Weber, M. The global burden of group A streptococcal diseases. Lancet Infect. Dis. 2005, 5, 685-694. [CrossRef]

77. Van Driel, M.L.; De Sutter, A.I.; Habraken, H.; Thorning, S.; Christiaens, T. Different antibiotic treatments for group A streptococcal pharyngitis. Cochrane Database Syst. Rev. 2016, 2016, CD004406. [CrossRef] [PubMed]

78. World Health Organization. Critically Important Antimicrobials for Human Medicine; 6th Revision; World Health Organization: Geneva, Switzerland, 2019; License: CC BY-NC-SA 3.0 IGO; Available online: https://apps.who. int/iris/bitstream/handle/10665/312266/9789241515528-eng.pdf?ua=1. (accessed on 12 October 2020).

79. Hsia, Y.; Lee, B.R.; Versporten, A.; Yang, Y.; Bielicki, J.; Jackson, C.; Newland, J.; Goossens, H.; Magrini, N.; Sharland, M. Use of the WHO Access Watch, and Reserve classification to define patterns of hospital antibiotic use (AWaRe): An analysis of paediatric survey data from 56 countries. Lancet Glob. Health 2019, 7, e861-e871. [CrossRef]

Publisher's Note: MDPI stays neutral with regard to jurisdictional claims in published maps and institutional affiliations.

(C) 2020 by the authors. Licensee MDPI, Basel, Switzerland. This article is an open access article distributed under the terms and conditions of the Creative Commons Attribution (CC BY) license (http://creativecommons.org/licenses/by/4.0/). 